\title{
Earnings Management: A Review on Family Ownership
}

\author{
Dr. Wan Fadzilah Wan Yusoff ${ }^{1}$, Aklima Akter ${ }^{* 1}$, Mohamad Ali Abdul-Hamid ${ }^{1}$
}

\author{
${ }^{1}$ Putra Business School University Putra Malaysia UPM Serdang, Selangor, Malaysia \\ *Corresponding author e-mail: aklima3rd@yahoo.com
}

\begin{abstract}
The purpose of this study is to synthesize the existing research regarding earnings management practices in family firms. This research reviews the existing knowledge about earnings management practices in family firms, analyzing the findings and the theoretical frameworks used in the prior literature. The results of this study have found that the prior empirical research identified the theoretical framework mainly based on agency theory. This study also finds that the existing literature uses two types of research study, namely, how different types of family firms manage earnings and the comparative scenario of earnings management between family and nonfamily firms. This paper adds values to the current literature by identifying the gaps in the existing literature and suggesting avenues for future research. The study has significant implications as it helps to develop the theoretical framework to understand the distinguishing characteristics of family firms and their engagement in earnings management practices.
\end{abstract}

Keywords-Earnings management, Family ownership, Agency theory.

\section{INTRODUCTION}

Since earnings management has considered a vital research study in the field of financial accounting in the last few years [1], less attention has devoted to discovering the accounting behavior regarding family firms [2]. Salvato $\&$ Moores [3] claims that the publicly held firms have received more attention in their accounting practices relative to family firms. It is not a matter of surprise that the prior empirical literature has given its primary focus on publicly-held firms in the UK and the USA while there is an existing predominant widespread structure of ownership [4]. Although the widespread structure of ownership is predominant only in the perspective of the USA and the UK in the eyes of the corporate world, these firms may have a minor focus. As family firms (FFs) are the most prevalent and the oldest form of ownership firms throughout the world $[5,6]$, in other countries especially with emerging economies, most firms dominated by family ownership [4]. So, how the business decision-making process and business outcomes have affected by family engagement in a firm's ownership, governance, and management is a growing research interest over the world $[7,8]$.

Recent literature asserts that family-owned firms ensure a greater quality of financial disclosure with lesser earnings management compared to non-family firms [914]. This literature also highlights different hierarchybased structures in the family firms like predominance in the economic systems with ownership concentration that has a strong influence on accounting practices, including earnings management because of weak corporate governance and less protection of minority shareholders[15]. This literature also documents the theoretical frameworks regarding earnings management in family firms, while agency theory is more crucial in achieving the firm-level financial objectives. In contrast, the socioemotional theory has also analyzed where the firm is connected with the non-financial objectives for long term sustainability.

This study focuses on quantitative research based on earnings management practices in family firms. The majority of the prior research has used abnormal accruals proxies for measuring earnings management. A few researches have highlighted real earnings management and accounting-based valuation model. This current research study also limits based on these three measurements of earnings management.

By investigating the existing literature on family firms' earnings management, the current study begins with the discussion of the fundamental theories used in the previous literature and their rationalities in managing earnings of firms with family nature in section 2 . Section 3 highlights different dimensions of earnings management practices in family firms, and section 4 presents conclusions and suggestions for future researchers. 


\section{THEORIES APPLIED IN THE EXISTING LITERATURE ON EARNINGS MANAGEMENT PRACTICES IN FAMILY FIRMS}

Table 1 shows that the prior extant studies of earnings management in family-owned firms have used mainly two types of theories, i.e., i) agency theory; and ii) socioemotional wealth (SEW) theory. In the current literature, agency theory has considered as the dominant and vital theory in designing the theoretical research framework compare to other theories in accounting practices [3]. This is the same in the prior research of earnings management practices in family firms $[9,10,21,11,13,14,16-20]$.

\section{A. Agency Theory}

The extent of earnings management practices in the family firms has determined by the two features: ownership concentration and control by family-owned firms (Type I agency problems), on the one hand, and entrenchment of the executives (Type II agency problems), on the other hand. Type I agency problems are associated with the distinction between control and ownership, which creates a divergence of interest between owners and managers [22]. Comparatively, the agency problems (Type II) arises when there exist conflicts between non-controlling and controlling shareholders in the family firms [23]. The Countries with decentralized ownership call for Type I agency problem (for example, in the USA). In contrast, Chi et al. [20] argue that the agency problem with type II nature is common in less developed countries with concentrated ownership in the hands of a single owner, which is consistent with the findings of Ding et al. [21].

The agency problems with type I nature are less severe in the family firms as management and ownership overlap to a significant level. Therefore, the empirical literature on family firms asserts that ownership concentration in the family firms leads to strong monitoring of the management. However, the strong monitoring by family ownership is likely to lessen the opportunistic behavior by the management and thus reducing earnings manipulation with better financial reporting. In the USA and European countries, the prior investigations have documented that the Type 1 nature of agency problems are less intense in the family firms; which lessen the earnings management and thus increasing the quality of the financial reporting $[9,11-$ 14].

In family-owned firms, Type II nature of agency problems is often more severe when conflicts arise between controlling and a non-controlling group of shareholders. Due to the dominancy of family owners, the agency problem transfer from manager-owner conflicts to majority-minority conflicts. A growing body of empirical research has highlighted that Type II agency problems are more critical in less developed countries. For example, Ding et al. [21] argue that the controlling interest by the founding family firms seeks personal benefit by expropriating the minority shareholders in the firms with weak corporate governance environment; the similar arguments have given by the study of Chi et al. [20]. Despite the existing conflicts between the group of majority and minority shareholders in the family firms, agency theory is not useful equally if non-financial factors are given priority in the accounting decision making process. The agency theory in the family firms alone may lessen the chance for interpreting the earnings management [3]. Considering this situation calls for the significant use of socioemotional theory in family firms.

\section{B. Socio-Emotional Wealth Theory (SEW)}

In contrast to agency theory, in recent years, the socioemotional wealth theory (SEW) has developed a theoretical framework in the area of family business study [24]. A lens of investigation on family firms' earnings management has emphasized on the non-financial factors influencing the decision-making process where family objectives aligned with ultimate business objectives-SEW $[12,17,25]$. Prencipe et al. [24] have developed the concept of SEW theory emphasizing that family firms are more committed to preserving the socioemotional wealth as "non-financial affect-related values including, for example, the fulfillment of the needs for belonging, affect, and intimacy; identification of the family with the firm; a desire to exercise authority and to retain influence and control within the firm; continuation of family values through the firm; preservation of family firm social capital and the family dynasty; discharge of familial obligations; and the capacity to act altruistically towards family members using firm resources."

Tommasetti et al. [17] have emphasized that socioemotional wealth is most influential in the younger family (founding family) firms than older (later) generations as they are closely associated with nonfinancial goals. The authors also mentioned that older generations attached less weight to protect their socioemotional wealth and therefore achieve a lower incentive to involve in earnings management. Martin et al. [11] have documented that the concept of socioemotional wealth theory encourages dominant family principals to protect their socioemotional wealth by discouraging executives from engaging earnings management activities. In the same way, Achleitner et al. [12] used the socioemotional wealth theory concept for better financial reporting by family firms. By using the theoretical concept of socioemotional wealth theory, the authors also argue that long term sustainability and control should be the prime concern to the family firms that help them to downward earnings management.

\section{DIMENSIONS OF EARNINGS MANAGEMENT PRACTICES IN FAMILY FIRMS}

Table 1 highlights two significant dimensions of prior research in managing the earnings of family-owned firms. The first dimension of research studies scrutinizes how family firms manage earnings relative to non-family firms. Comparatively, the other dimension of this study explores how earning management differs within the heterogeneity of family firms.

\section{A. How does Earnings Management Practice by the Family Firms Compare to Non-Family Firms?}

Empirical studies on US countries generally hold the opinion that family-owned firms have lower earnings management with high financial reporting disclosures 
compared to their counterparts of non-family firms $[11,13$, 14]. These all empirical research has calculated abnormal accruals of earnings management by using the Jones [26] model and by its different modifications, for example, of Dechow et al. [27] model. Overall, the findings based on US firms ensure that family firms report higher earnings quality with low earnings management compared to their non-family counterparts. These studies also have documented that family firms exert supreme dominant power on the management, including superior voting rights directly or indirectly.

In line with the US studies, the research on European countries, for example, Borralho et al.[9] have reported using Spanish companies that family-owned firms provided higher-financial disclosures with lower earnings management compared to their non-family owned firms. The study has also documented that dominant family (families) based on European firms hold the majority of voting rights directly or indirectly and at least one member of the family participants in the governance or management position. Similarly, using the sample of Germany listed firms, the study of Achleitner et al.[12] have found the same results. In contrast, Paiva et al.[16] have reported using the sample from the UK that family firms are more prone to involve in managing earnings rather than nonfamily firms, except they are followed by some significant analysts, for example, intense monitoring by the governance. The study also argues that weak external governance is responsible beyond the manipulation by the family firms.

Thus, prior literature has documented that majority of the family firms in the US, and Europe countries face less intense Type 1 nature of agency problem by comparing with the non-family firms caused by the segregation of the management and proprietorship; which rationalize to the family firms in managing healthier financial reporting $[9,11-14]$.

Chi et al. [20] and Ding et al.[21] opine that nonfamily firms are less prone to involve in the gambling of earnings manipulation rather than family-owned firms, which is contrary to the findings on the US and European countries. Using the sample of Taiwan, Chi et al. [20] [20] have identified that family firms exhibit more abnormal accruals than non-family firms. Their findings also claim that independent directors can reduce the possibility of earnings management by family members. At the same time, the presence of CEO duality as an interacted variable can increase that manipulation. Others, Ding et al. [21] have investigated the accounting earnings in Chinese listed family firms. The authors have reported that Chinese family firms seek their benefits beyond the interest of minority shareholders and have shown lower earnings quality with higher earnings management. The investigation also claims that Chinese family-owned firms involve in lower conservative accounting practices compared to their non-family firms.

In contrast, employing the sample of Pakistani listed firms, Arsalan et al.[10] have investigated that family firms tend to disclose the better quality of earnings by lessening earnings management than non-family firms. They have also argued that the presence of political connections in the family firms can reduce the quality of earnings compared to their non-connected firms.

Overall, the findings from China and Taiwan contrast with the findings in the US and Europe except for the study of [16]. The Type II nature of agency problems is more severe issues in China and Taiwan with high levels of earnings management of the family firms. In contrast, Type I nature of the agency problems are a less severe issue in the family firms of Pakistan in line with the US and Europe.

\section{B. How do Earnings Management Practices differ Based on Different Categories of Family Firms?}

The majority of the prior empirical literature has mainly focused on earnings management practices in family firms by comparing with the non-family firms. But, there is dearth research on the determinants of earnings management practices in the heterogeneity of family firms.

The latest study by Tommasetti et al.[17] focuses on the variants in earnings management between the heterogeneous group of family firms of the Brazilian B3 primary market (i.e., family firms at the different generational stage). The findings of this research demonstrate that older family firms are less prone to engage in earnings management practices than younger (founding) family firms. The authors argue that older generational stages in the family firms enjoying less weight to preserve their socioemotional wealth and thus are reluctant to engage in higher earnings management practices than firms in the earlier stage. Comparatively, Kriengkrai \& K[28] examine the effect of founding family Thai listed firms on earnings management and find that founding family firms ensure high earnings quality rather than non-founding family and other controlling family firms. The authors provide strong evidence on the fact that founding family firms needed less corporate governance practices as they provide high-quality earnings compared to other controlling firms.

Another recent study by Razzaque et al. [18] examines the effects of family firms on real earnings management on Bangladeshi listed firms. The study demonstrates that the curvilinear relationship is existing between REMs \& family ownership; REM is higher at the earlier stage and started to decrease with the surge of family ownership. The authors provide strong evidence on the fact that higher family ownerships will tend to decrease earning management by maintaining a larger association of interest between the majority and minority group of shareholders.

Using samples from firms listed by the Canada, United States, Spain, the United Kingdom, Italy, and France, from 2008 to 2013, Jara Bertin \& Lopez Iturriaga[15] investigate how the decentralization of power among different family owners influences to earnings management. The study results show that more significant dominant shareholders are more involving in earnings management than minority shareholders in family firms. The researchers also argue that this competition is more crucial in countries where investors' rights are less protective. 
Pazzaglia et al.[25] investigate the nature of earnings quality existing in various types of family firms (i.e., Family owners through market transactions or inherited by family owners) listed in Italy. The results show that family firms acquired through market transactions report more earnings manipulation because of less recognition of family members in the firm than firms inherited by family owners or acquired through market transactions. The authors of this study argue that the process of acquiring ownership by the family members is the key driving factor that affects the quality of earnings disclosed by the family firms.

Finally, Stockmans et al.[19] present the earnings management practices in controlling and non-controlling private family firms listed by the Belgian in 2003. The findings of this study provide evidence that the presence of external directors \& CEO duality will reduce earnings management practices by mitigating significant agency problems aroused in the family firms.

\section{CONCLUSIONS AND AVENUES FOR FUTURE}

\section{RESEARCH}

This research study has broadly focused on earnings management practices in family firms by documenting the fundamental theories: agency theory and socio-emotional wealth theory. The current study also categorizes family firms from two main aspects (comparative scenario of earnings management family firms with non-family firms and the nature of managing earnings of the heterogeneous of family firms).

The extant literature on earnings management practices in the family by comparing with the non-family firms focus on how family-owned firms influence financial reporting disclosure when the agency problems of Type II dominated by the Type I. The prior research indicate that the magnitude of earnings management emphasizing on the European and US economies show higher levels of earnings quality (lesser level of earnings management) in family firms. On the contrary, studies based on less developed countries (like China, Taiwan) assert that family-owned firms are more prone to engage in gambling of earnings management because of existing weak institutional environment, concentrated ownership, lower transparency in financial reporting and expropriation of minority shareholders by the majority for seeking private gains in the family firms.

The academicians, policymakers, and future researchers should give attention to the institutional aspects and explore its association in managing the earnings of the family-owned firms. For example, a future researcher would add to the previous literature on how transparency of financial reporting in a family firm can affect earnings management. Given that we are not sincere in the study of the firms that are adopting International Financial Reporting Standards (IFRS), but the study on family firms showing the impact of IFRS will be most welcome.

Research-based on the second category of family firms, i.e., earnings management of heterogeneous family firms is qualified as scarce, especially on non-listed family firms. Because it is difficult to find out data from privately owned family firms as well as at the same time the easy access of publicly archived data of financial reporting in most of the research [24]. Qualitative research, surveybased research, and experimental research on non-listed family firms could be added to the current literature. The collection of data on earnings management practices in these ways that are not available in the public database will significantly increase our knowledge.

From the perspective of the theoretical framework, it is notably mentionable that the prior researchers have considered agency theory as the most useful theory for investigating family firms' earnings management. Due to the emphasis on firm-level governance and ownership by the agency theory, it has limited power for achieving firms' non-economic objectives [24].

Recently, the socioemotional theory that focuses on non-financial factors has begun to use by the researcher in investigating earnings management practices in family firms. Although this study highlights the increasing interest in using socioemotional theory, still, the study in this research field is limited. Considering the significance of socio-psychological aspects in family-owned firms in earnings management [12], the current study suggests that there have to be given more devotion to these issues for a better understanding by the future academician, policymaker, and researchers. Besides, other theories highlighting on non-economic factors scarcely used in the previous literature can also be significant assistance for improving the perspective of earnings management in family firms, for instance, stewardship theory [9], transaction cost theory [29], and stakeholder theory [30].

The majority of empirical literature has focused earnings management of the homogeneous group of the family- firms. But a little attention is given on the heterogeneity group of family firms, i.e., in different categories of family firms. This research suggests that when exploring earnings management in the family firms, their heterogeneity (such as firms acquired through inherited or market transactions by the family member, succession vis-a-vis non-succession family-owned firms) can add new insights about the divergent interest of the family firms and thus, divergent rewards for managing earnings of heterogeneous family firms. Therefore, the study suggests the necessity of exploring the diverse kinds of research, such as qualitative or survey research, as well as multiple theoretical frameworks. Finally, it expects that this study will inspire future researchers in the empirical and theoretical research fields.

\section{REFERENCES}

Shu P-G, Chiang S-J. Firm size, timing, and earnings management of seasoned equity offerings. Int Rev Econ Financ; 29: 177-194, 2014

[2] Prencipe A, Bar-Yosef S. Corporate governance and earnings management in family-controlled companies. $J$ Accounting, Audit Financ; 26: 199-227, 2011.

Salvato C, Moores K. Research on accounting in family firms: Past accomplishments and future challenges. 23. Epub ahead of print. DOI: https://doi.org/10.1177/0894486510375069, 2010. 
[4] Bhaumik SK, Gregoriou A. 'Family'ownership, tunnelling and earnings management: A review of the literature. J Econ Surv 24: 705-730, 2010.

[5] Bassetti T, Dal Maso L, Lattanzi N. Family businesses in Eastern European countries: How informal payments affect exports. J Fam Bus Strateg; 6: 219-233, 2015.

[6] Miralles-Marcelo JL, del Mar Miralles-Quirós M, Lisboa I. The impact of family control on firm performance: Evidence from Portugal and Spain. J Fam Bus Strateg; 5: 156-168, 2014.

[7] Kim Y, Park MS, Wier B. Is earnings quality associated with corporate social responsibility? Account Rev; 87: 761-796, 2012.

[8] Lin Y-M, Shen C-A. Family firms' credit rating, idiosyncratic risk, and earnings management. J Bus Res; 68: 872-877, 2015.

[9] Borralho JM, Vázquez DG, Hernández-Linares R. Earnings management in private family versus non-family firms. The moderating effect of family business generation. Spanish $J$ Financ Account / Rev Española Financ y Contab 2020; 49: 210-233.

[10] Arsalan HM, Khresna BR, Evan L. Political connections, family firms and earnings quality. Manag Res Rev; 41: 414-432, 2018.

[11] Martin G, Campbell JT, Gomez-Mejia L. Family control, socioemotional wealth and earnings management in publicly traded firms. J Bus Ethics; 133: 453-469, 2016.

[12] Achleitner A-K, Günther N, Kaserer C, et al. Real earnings management and accrual-based earnings management in family firms. Eur Account Rev; 23: 431-461, 2014.

[13] Jiraporn P, DaDalt PJ. Does founding family control affect earnings management? Appl Econ Lett; 16: 113-119, 2009.

[14] Tong YH. Financial Reporting Practices of Family Firms. $A d v$ Account; 23: 231-261, 2007.

[15] Jara Bertin M, Lopez Iturriaga FJ. Earnings management and the contest to the control: an international analysis of familyowned firms. Spanish J Financ Accounting/Revista Española Financ y Contab 2014; 43: 355-379.

[16] Paiva IS, Lourenço IC, Dias Curto J. Earnings management in family versus non-family firms: the influence of analyst coverage. Spanish J Financ Account / Rev Española Financ y Contab; 48: 113-133, 2019.
[17] Tommasetti R, da Silva Macedo MA, da Silva Constantino F de $\mathrm{F}$, et al. Family control and earnings management in Brazilian listed companies: a relationship mediated by age. Rev Universo Contábil; 15: 151-169, 2019.

[18] Razzaque RMR, Ali MJ, Mather PR. Real earnings managemen in family firms: Evidence from an emerging economy. PacificBasin Financ J; 40: 237-250, 2016

[19] Stockmans A, Lybaert N, Voordeckers W. The conditional nature of board characteristics in constraining earnings management in private family firms. J Fam Bus Strateg; 4: 84 92,2013

[20] Chi CW, Hung K, Cheng HW, et al. Family firms and earnings management in Taiwan: Influence of corporate governance. Int Rev Econ Financ; 36: 88-98, 2015.

[21] Ding S, Qu B, Zhuang Z. Accounting properties of Chinese family firms. J Accounting, Audit Financ; 26: 623-640, 2011.

[22] Jensen C, Meckling H. Theory of the firm : managerial behavior , agency costs and ownership structure; 3: 305-360, 1976.

[23] Fama EF, Jensen MC. Separation of Ownership and Control. $J$ Law Econ; 26: 301-325, 1983

[24] Prencipe A, Bar-Yosef S, Dekker HC. Accounting Research in Family Firms: Theoretical and Empirical Challenges. Eur Account Rev; 23: 361-385, 2014.

[25] Pazzaglia F, Mengoli S, Sapienza E. Earnings quality in acquired and nonacquired family firms: A socioemotional wealth perspective. Fam Bus Rev 2013; 26: 374-386.

[26] Jones JJ. Earnings management during import relief investigations. J Account Res; 29: 193-228, 1991.

[27] Dechow PM, Sloan RG, Sweeney AP. Detecting earnings management. Account Rev; 70: 193-225, 1995.

[28] Kriengkrai B-U-T, K. SP. Family ownership and earnings quality of Thai firms. Asian Rev Account; 27: 112-136, 2019.

[29] Memili E, Chrisman JJ, Chua JH, et al. The determinants of family firms' subcontracting: A transaction cost perspective. $J$ Fam Bus Strateg; 2: 26-33, 2011.

[30] Zellweger TM, Nason RS. A Stakeholder Perspective on Family Firm Performance. Fam Bus Rev; 21: 203-216, 2008.

\section{APPENDIX}

TABLE 1. PRIOR EMPIRICAL RESEARCH REGARDING EARNINGS MANAGEMENT OF FAMILY FIRMS

\begin{tabular}{|c|c|c|c|c|}
\hline Author(s)\& Year & Sample \& Data period & $\begin{array}{c}\text { Earnings Management } \\
\text { Measurement Techniques }\end{array}$ & Theoretical Approach & Findings \\
\hline \multicolumn{5}{|c|}{ Part A: How does the family firm practiced earnings management compare to non-family firms? } \\
\hline Borralho et al. [9] & $\begin{array}{l}263 \text { unlisted Spanish } \\
\text { companies, from } 2011 \text { - } \\
2015\end{array}$ & $\begin{array}{c}\text { Discretionary Accruals- } \\
\text { modified Jones model as } \\
\text { proposed by Dechow et al., } \\
\text { (1995) }\end{array}$ & $\begin{array}{c}\text { Agency theory \& } \\
\text { Stewardship theory }\end{array}$ & $\begin{array}{c}\text { Family firms are less likely } \\
\text { to involve in earnings } \\
\text { management than non- } \\
\text { family firms. }\end{array}$ \\
\hline Paiva et al. [16] & $\begin{array}{l}1,043 \text { firms ( } 112 \text { family } \\
\text { firms and } 931 \text { non-family } \\
\text { firms) listed in the UK, } \\
\text { from } 2006-2010\end{array}$ & $\begin{array}{l}\text { Absolute value of } \\
\text { Discretionary Accruals- } \\
\text { modified-Jones (m-J) } \\
\text { model with the ROA } \\
\text { (current-year) }\end{array}$ & $\begin{array}{c}\text { Agency theory \& } \\
\text { Socioemotional wealth } \\
\text { theory }\end{array}$ & $\begin{array}{c}\text { Family firms report a } \\
\text { higher level of earnings } \\
\text { management relative to } \\
\text { non-family firms. }\end{array}$ \\
\hline Arsalan et al. [10]) & $\begin{array}{l}238 \text { Pakistani listed non- } \\
\text { financial firms, covering } \\
\text { the period from } 2009 \text { to }\end{array}$ & $\begin{array}{l}\text { 1. Discretionary Accruals- } \\
\text { Jones (1991) model } \\
\text { 2. Discretionary Accruals - }\end{array}$ & Agency theory & $\begin{array}{l}\text { Family firms report high- } \\
\text { quality earnings with fewer } \\
\text { earnings management than }\end{array}$ \\
\hline
\end{tabular}




\begin{tabular}{|c|c|c|c|c|}
\hline Author(s)\& Year & Sample \& Data period & $\begin{array}{c}\text { Earnings Management } \\
\text { Measurement Techniques }\end{array}$ & Theoretical Approach & Findings \\
\hline & 2015 & $\begin{array}{c}\text { modified Jones model as } \\
\text { proposed by Dechow et al. } \\
\text { (1995) } \\
\text { 3. Performance Matched } \\
\text { Discretionary Accruals } \\
\text { Kothari, Leone, and Wasley } \\
\text { (2005) }\end{array}$ & & non-family firms. \\
\hline Chi et al. [20] & $\begin{array}{l}378 \text { Taiwan firms from } \\
2006 \text { to } 2012\end{array}$ & $\begin{array}{c}\text { Abnormal Accruals -(AA)- } \\
\text { modified-Jones (m-J) } \\
\text { model }\end{array}$ & Agency theory & $\begin{array}{l}\text { Family firms exhibit a } \\
\text { higher level of discretionary } \\
\text { accruals compared to non- } \\
\text { family firms. }\end{array}$ \\
\hline Achleitner et al. [12] & $\begin{array}{l}838 \text { firms ( } 402 \text { families \& } \\
436 \text { non-families) listed in } \\
\text { Germany, covering the } \\
\text { period from } 1998 \text { to } 2008\end{array}$ & $\begin{array}{l}\text { 1. REM- Cohen, Dey, and } \\
\text { Lys (2008) Model } \\
\text { 2. ABEM- Model Dechow } \\
\text { and Dichev (2002) Model }\end{array}$ & $\begin{array}{l}\text { Socioemotional wealth } \\
\text { theory }\end{array}$ & $\begin{array}{c}\text { Family firms are less } \\
\text { involving in REM and also } \\
\text { showing a lower value of } \\
\text { discretionary accruals than } \\
\text { non-family firms. }\end{array}$ \\
\hline Ding et al. [21] & $\begin{array}{l}1542 \text { firm-year } \\
\text { observations, Chinese non- } \\
\text { state listed companies, from } \\
\text { 2003-2006 }\end{array}$ & $\begin{array}{l}\text { Abnormal Accruals- } \\
\text { Performance Matched } \\
\text { Discretionary Accruals } \\
\text { Model developed by } \\
\text { Kothari et al. (2005) }\end{array}$ & Agency theory & $\begin{array}{l}\text { Family firms present a } \\
\text { higher level of discretionary } \\
\text { accruals than non-family } \\
\text { firms. }\end{array}$ \\
\hline Jiraporn \& DaDalt [13] & $\begin{array}{l}805 \text { firm-year observations } \\
\text { from US, 1994-1999 }\end{array}$ & $\begin{array}{l}\text { Abnormal Accruals- } \\
\text { modified-Jones (m-J) } \\
\text { model developed by } \\
\text { Dechow et al. (1995) }\end{array}$ & Agency theory & $\begin{array}{l}\text { Family firms show a low } \\
\text { value of discretionary } \\
\text { accruals compared to non- } \\
\text { family firms. }\end{array}$ \\
\hline Tong,[14] & $\begin{array}{l}3,040 \text { (1,057 family firms } \\
\text { and } 1,983 \text { non-family } \\
\text { firms) US firm-year } \\
\text { observations, } 1992-2003\end{array}$ & $\begin{array}{l}\text { Abnormal Discretionary } \\
\text { Accruals-modified Jones } \\
\text { model } 1991 \text { after } \\
\text { controlling operation from } \\
\text { cash flows. }\end{array}$ & Agency theory & $\begin{array}{l}\text { Family firms report lower } \\
\text { discretionary accruals with } \\
\text { high informative earnings } \\
\text { relative to their non-family } \\
\text { firms. }\end{array}$ \\
\hline \multicolumn{5}{|c|}{ Part B: How do earnings management practices differ based on different categories of family firms? } \\
\hline Tommasetti et al. [17] & $\begin{array}{l}755 \text { Brazilian listed firm- } \\
\text { year observations, during } \\
\text { 2012-2016 }\end{array}$ & $\begin{array}{c}\text { Discretionary (abnormal) } \\
\text { Accruals- } \\
\text { Jones (1991) model }\end{array}$ & $\begin{array}{c}\text { Agency theory } \\
\text { \& Socioemotional wealth } \\
\text { theory }\end{array}$ & $\begin{array}{l}\text { Older family firms are less } \\
\text { engaging in earnings } \\
\text { management practices than } \\
\text { younger (founding) family } \\
\text { firms. }\end{array}$ \\
\hline Kriengkrai \& K. [28] & $\begin{array}{c}\text { 1,562 Thai listed firm-year } \\
\text { observations, during 2000- } \\
2007\end{array}$ & $\begin{array}{l}\text { Accounting-based valuation } \\
\text { model-Model developed by } \\
\text { Qu and Zhang (2015) }\end{array}$ & $\begin{array}{l}\text { Fundamental } \\
\text { valuation theory }\end{array}$ & $\begin{array}{l}\text { Founding family firms } \\
\text { ensure better earnings } \\
\text { quality than non-founding } \\
\text { family and other controlling } \\
\text { family firms. }\end{array}$ \\
\hline Razzaque et al. [18] & $\begin{array}{l}122 \text { Bangladeshi firms } \\
\text { listed in Dhaka Stock } \\
\text { Exchange (DSE), during } \\
\text { 2006-2011 }\end{array}$ & $\begin{array}{c}\text { Real Earnings Management } \\
\text { (REM) measurement as } \\
\text { developed by } \\
\text { Roychowdhury (2006) \& } \\
\text { Cohen et al. (2008) } \\
\text { 1. Abnormal Cash Flows } \\
\text { from operations } \\
\text { 2. Abnormal Discretionary } \\
\text { Expenses } \\
\text { 3. Abnormal production } \\
\text { costs }\end{array}$ & Agency theory & $\begin{array}{l}\text { The curvilinear linkages } \\
\text { exist between REMs \& } \\
\text { family ownership; REM is } \\
\text { higher at the earlier stage } \\
\text { and started to decrease with } \\
\text { the increase of family } \\
\text { ownership. }\end{array}$ \\
\hline $\begin{array}{l}\text { Jara Bertin \& Lopez } \\
\text { Iturriaga, [15] }\end{array}$ & $\begin{array}{l}3,559 \text { firms listed by } \\
\text { Canada, the United States, } \\
\text { Spain, the United Kingdom, } \\
\text { Italy, and France from } \\
2008 \text { to } 2013\end{array}$ & $\begin{array}{l}\text { Discretionary Accruals- } \\
\text { Performance Model of } \\
\text { Kothari et al. (2005) }\end{array}$ & - & $\begin{array}{c}\text { Larger dominant } \\
\text { shareholders are more } \\
\text { involving in earnings } \\
\text { management than minority } \\
\text { shareholders in family } \\
\text { firms. }\end{array}$ \\
\hline Pazzaglia et al. [25] & $\begin{array}{l}\text { 1,254 Italian listed firm- } \\
\text { year observations ( } 311 \\
\text { acquired family firms \& } \\
943 \text { non-acquired family } \\
\text { firms and) during the period } \\
\text { of } 1995 \text { to } 2008\end{array}$ & $\begin{array}{l}\text { Abnormal Discretionary } \\
\text { Accruals-Dechow and } \\
\text { Dichev (2002) Model }\end{array}$ & $\begin{array}{l}\text { Socioemotional wealth } \\
\text { theory }\end{array}$ & $\begin{array}{l}\text { Family firms acquired } \\
\text { through market transactions } \\
\text { report more earnings } \\
\text { manipulation than firms } \\
\text { inherited by family owners. }\end{array}$ \\
\hline
\end{tabular}




\begin{tabular}{|c|c|c|c|c|}
\hline Author(s)\& Year & Sample \& Data period & $\begin{array}{c}\text { Earnings Management } \\
\text { Measurement Techniques }\end{array}$ & Theoretical Approach & Findings \\
\hline & during 2003. & $\begin{array}{l}\text { Accruals- Performance } \\
\text { Model developed by } \\
\text { (Kothari et al. (2005)) }\end{array}$ & & $\begin{array}{l}\text { directors \& CEO duality } \\
\text { will reduce earnings } \\
\text { management practices by } \\
\text { private family firms. }\end{array}$ \\
\hline
\end{tabular}

